\title{
An experimental evaluation of continuous normothermic, intermittent hypothermic, and intermittent normothermic coronary perfusion
}

\author{
A. HEDLEY BROW ${ }^{1}, M$. V. BRAIMBRIDGE, \\ SALLY DARRACOTT ${ }^{2}$, J. CHAYEN ${ }^{3}$, and H. KASAP4 \\ Department of Cardiothoracic Surgery, St. Thomas' Hospital, London SE1
}

\begin{abstract}
Hedley Brown, A., Braimbridge, M. V., Darracott, Sally, Chayen, J., and Kasap, H. (1974). Thorax, 29, 38-50. An experimental evaluation of continuous normothermic, intermittent hypothermic, and intermittent normothermic coronary perfusion. Coronary perfusion and hypothermia both have disadvantages, and excellent clinical results are obtained without them, though short operations, spontaneous cooling of unperfused hearts, hyperglycaemia, heparinization, and young and cyanotic subjects may allow more tolerance of ischaemia. Functional, macroscopic, histological, ultrastructural, chemical, and metabolic evidence of the inadvisability of ischaemia, especially of hypertrophied hearts, abounds, though statistical support and histochemical proof are lacking.

Isovolumic function tests permit accurate assessment of compliance. Succinic dehydrogenase distribution is the most relevant enzyme assay of myocardial transport; freed phospholipids indicate cellular membrane disorganization. Adenosinetriphosphate response of myosin (myocardial ATP ase) is shown quantitatively by change of birefringence. Ventricular oedema may be detected by changes in weight. These tests were used to compare continuous normothermic, intermittent hypothermic, and intermittent normothermic perfusion over two hours in isolated, cross-perfused canine hearts. Isolated hearts are very sensitive to imperfections of maintenance, but cross-perfusion minimizes perfusion-induced deterioration.

Normothermic continuously perfused hearts performed significantly better than intermittently perfused hearts, among which cooled hearts functioned better than normothermic hearts after two hours. Succinic dehydrogenase and acid haematein tests showed significant benefit from cooling during intermittent perfusion. The experimental preparation and techniques of assessment proved sensitive enough to demonstrate these differences, though cooling preserved cellular enzymes better than it did function. This work gives histochemical and statistical support to existing evidence that intermittent ischaemia for two hours can be ameliorated by moderate hypothermia but is not as effective for myocardial maintenance as constant perfusion with normal blood.
\end{abstract}

\section{PERFUSION OF THE CORONARY ARTERIES}

The continuous improvement in the results of cardiac surgery makes it difficult to demonstrate retrospectively the benefit of any particular technique. Continuous coronary perfusion became popular when mortality rates for cardiac surgery were falling but was not necessarily responsible

1Cardiothoracic Surgical Department, The Wellington Hospital, New Zealand

2The Cardiac Histochemistry Laboratory, St. Thomas' Hospital 3The Mathilda and Terence Kennedy Institute of Rheumatology, London W6

4Department of Social Medicine, St. Thomas' Hospital Medical School for this fall, as many other factors were improving at this time. Continuous perfusion is, however, still applied during most cardiac operations even though it may itself damage the heart. Excessive pressure may be applied through coronary cannulae (Shaw et al., 1962) which may damage the myocardium (Brown et al., 1969; Kay et al., 1961) and reduce the compliance of the heart (Cross, Reiben and Salisbury, 1961), especially when associated with haemodilution, electrical defibrillation, disposable bubble-oxygenators, and overdistension of the heart (Salisbury et al., 1961). Platelet emboli may be introduced into coronary circulation (Taber, Morales, and Fine, 1967), as well as air 
and antifoam, and the coronary cannulae may themselves damage the arteries (Morales, Fine, and Taber, 1967; Ramsey et al., 1967; Trimble et al., 1969). Ventricular hypertrophy, common in cardiac surgical subjects, increases these risks and makes adequate perfusion of all the tissue less likely, especially if coronary artery disease be present (Björk, 1967). Early bifurcation of the coronary artery may result in perfusion of only one branch by a cannula, and this risk, and that of other coronary artery disease or anomaly, makes coronary angiography necessary before cannulation at surgery (Singh and Horton, 1971). Moreover, the provision of coronary perfusion does not prevent ischaemic enzyme changes during aortic valve surgery (Littler et al., 1972). The dangers of coronary perfusion may thus outweigh its benefits (Robicsek et al., 1970).

\section{HYPOTHERMIA}

Even perfusion of the heart from the aorta may be overdone, with resulting myocardial damage, when the cooling of the heart or the presence of ventricular fibrillation disturbs the autoregulation of coronary flow (Vasko, 1967). Moderate hypothermia to about $30^{\circ} \mathrm{C}$ is a frequently used safeguard and doubles the duration of anoxia which the heart can tolerate without loss of function (Enright, Staroscik, and Reis, 1970). With cooling, however, the myocardium stiffens and is less easily retracted, and its normal energy sources are changed (Calman et al., 1971) as the uptake of non-esterified fatty acids and ketones is decreased (Moffitt, Rosevear, and McGoon, 1966; Pitzele, Sze, and Dobell, 1971a and b). More than moderate hypothermia may expose the heart to more risk of oedema and rigor contraction bands during rewarming (Willman and Barner, 1969).

\section{NORMOTHERMIC ISCHAEMIA}

The feasibility of dispensing with coronary perfusion without needing hypothermia was shown by Bloodwell et al. in 1966: no difference in mortality, rate of recovery or postoperative electrocardiogram was seen between 50 patients given coronary perfusion and 127 whose operations were done without this provision. Goldman, whose time for aortic valve replacement was nearly twice that of the Houston group, stated that, from experimental evidence, periods of normothermic ischaemia of the heart exceeding 45 minutes could not be justified, but found that patients having this operation in his unit, without perfusion, went home sooner and survived as well as those for whom coronary perfusion was provided (Goldman et al., 1971). Further experience in humans has shown that periods of 54 minutes with one interval of perfusion, and 45 minutes with no perfusion, are safe and greatly simplify the procedure, reducing the chances of imperfect operations, which are a greater hazard to the patient's life than ischaemic myocardial damage (Reul et al., 1971). Carbon dioxide production is not minimal until 45 minutes of ischaemia (Gardner et al., 1971).

Even after 15-20 minutes of normothermic ischaemia, however, there is diminished function, for which the heart compensates by increasing its end-diastolic volume, and which can also be counteracted by isoprenaline (Sanmarco et al., 1969); after this time swelling of the mitochondria is seen, structural damage appearing after 30-40 minutes of ischaemia (Katz, 1968). The myocardial creatine phosphate has all disappeared after 6-7 minutes of ischaemia (Lundesgaard-Hansen, 1966). By 30 minutes of ischaemia, function is down to $80 \%$ of the initial value (Mundth et al., 1969): the mitochondrial changes observed (Caulfield and Klionsky, 1959) may also be seen after bypass without ischaemia for that time (Vitali-Mazza et al., 1969). After 40 minutes of ischaemia, changes can be seen by routine histological techniques (Bolooki et al., 1968), and after 45 minutes, extensive damage could be seen in 16 dogs' hearts (Buja et al., 1971) in the papillary muscles of the subendocardium, where it is so frequently seen in patients dying after open-heart surgery, especially when anoxic arrest was used (Colapinto and Silver, 1971). After an hour of ischaemia there is $38 \%$ loss of contractile velocity, or $58 \%$ when the ventricle is hypertrophied (Levitsky et al., 1971).

Human ventricular function also is depleted to a degree dependent on ischaemic time (Benzing, Helmsworth, Stockert, and Kaplan, 1970). About half of the lost function can be regained by subsequent perfusion but, after 72 hours, hearts which had been ischaemic for an hour were substantially worse than those which had not (Ecker et al., 1969). Ventricular compliance goes on falling for several days after an ischaemic insult, which could explain the late fall in cardiac output after surgery (Enright et al., 1970). Thus, all the functional, histological, and ultramicroscopic evidence shows that time and temperature are linearly correlated with myocardial damage: chemical analysis shows that catecholamine, potassium, and water loss from the cells, and sodium gain by them, are directly related to the time of ischaemia (Taggart et al., 1971). 
The difference between the experimental results of normothermic ischaemia and those of its clinical use could be explained by the cooling of the unperfused heart at operation, but not in the controlled conditions of the laboratory, to the temperature of the room or even lower by evaporation. Thus at room temperature, provided heparinization is adequate to prevent intravascular coronary thrombosis, the myocardium is still healthy after 90 minutes of ischaemia (Webb, Sugg, and Ecker, 1968); whereas $80 \%$ of function is lost after two hours of truly normothermic ischaemia, only $20 \%$ is lost at a temperature of $20^{\circ} \mathrm{C}$, which many hearts must reach at operation (Childs and Lower, 1969). The success of normothermic ischaemia in children may stem from their greater lipid utilization and insulin response, and in cyanotic children their later onset of anaerobic glycolysis in ischaemia (Moffitt, Rosevear, and McGoon, 1970). Raised blood sugar levels known to protect the heart from ischaemic damage (Hall et al., 1960; Yang, 1963) are usually found in the clinical circumstances of haemodilution-perfusion.

\section{THE TECHNIQUE OF EXPERIMENTAL EVALUATION}

In previous investigations (see above), ventricular function, histological and ultramicroscopic appearance, and chemical assay of amine, electrolyte, and water content of the myocardial cells have all proved useful. Ventricular function tests in human subjects can be performed (Benzing et al., 1970), though they are not truly isovolumic and therefore lack information on compliance. Myocardial redox potential or $\mathrm{pH}$ (Abbott, 1969) and lactate uptake (Levitsky et al., 1970) indicate the degree of cellular anoxia, and tetrazolium dye tests of a crude type (Terasaki, Martin, and Smith, 1967) show only late irreversible changes, as does the demonstration of myofibrillar degeneration by microscopy (Reichenbach and Benditt, 1968). Transient ischaemic changes can be shown by unipolar electrode electrocardiograms (Bayley, 1942) and by the demonstration of abnormal proteins in the cells (Kent, 1966; Lie et al., 1971). The freeing of phospholipids from their normal protein binding is a more accepted sign of loss of cellular integrity and can be detected by the Baker's acid haematein stain (Niles and Barnhouse, 1967). Myocardial hydrogen transport by dehydrogenase enzymes should also prove relevant to function; there is more succinic dehydrogenase in the heart than in other tissues (Verma and King, 1966), and it is the only enzyme found to be deficient in idiopathic cardiomegaly (Kobernick et al., 1963); the histo- logical localization of succinic dehydrogenase should be a good guide to the efficacy of myocardial preservation (Chayen et al., 1966). In addition to assessing the cellular integrity and the metabolic production of energy-rich phosphates, the conversion of these into work by adenosine triphosphatase should be examined. Direct staining of ATP'ase or examination of its physical response by birefringence (Veress et al., 1966; Brown et al., 1969) completes the appraisal.

\section{THE FORM OF THIS INVESTIGATION}

Isolated, perfused canine hearts, very sensitive to imperfections of their support system, but stable when cross-perfused (Londe, 1969), were used. Isovolumic ventricular function tests, with a balloon fixed in the left ventricular cavity, were performed before and after a two-hour period of uninterrupted normothermic perfusion with blood from another intact dog. Biopsies of the ventricles were performed with a high-speed air drill (Braimbridge and Niles, 1964) before and after the two-hour perfusion, and chilled to $-70^{\circ} \mathrm{C}$ for subsequent histological examination (Silcox et al., 1965). The same techniques were applied to a group of hearts maintained for two hours by intermittent (10 minutes of ischaemia to three minutes of perfusion) perfusion at normal temperature, and to another group in which the intermittent perfusion was done at $30^{\circ} \mathrm{C}$. The histological examination was of sections stained by routine haematoxylin and eosin, for succinic dehydrogenase and adenosine-triphosphatase, and by the acid-haematein technique for free phospholipids. The birefringence of the myocardial contractile elements was measured before and after the application of calcium and adenosine-triphosphate. Regression slopes of end-diastolic volume, peak systolic pressure, and peak rate of rise of pressure, against the end-diastolic pressure in the ventricle, were calculated. Contractile force, velocity, and compliance of the ventricles could be compared between groups at a standard end-diastolic pressure of $10 \mathrm{mmHg}$, expressing all results as ratios of values after the perfusion period to those before it. 'After/before' estimates of the amount of histological and histochemical damage found in the hearts were also compared. The significances of the differences found between the groups were calculated by Student's $t$ test.

\section{METHOD}

Ex-racing greyhounds, weighing 18-28 kg, were anaesthetized with $30-40 \mathrm{mg} / \mathrm{kg}$ of sodium pentobarbital and ventilated with $60 / 40 \quad \mathrm{~N}_{2} \mathrm{O} / \mathrm{O}_{2}$ mixture from a 
Starling pump, The chest was opened by median sternotomy and $25 \mathrm{mg}$ of lignocaine was injected into the pericardium. After intravenous injection of $5 \mathrm{mg} /$ $\mathrm{kg}$ of heparin, the aortic root was cannulated via the left subclavian artery and the right ventricle via the right atrial appendage. A second dog was similarly anaesthetized, ventilated, and heparinized, and its femoral arteries and veins were cannulated for bypass and pressure monitoring. The arterial cannula was connected to a calibrated pump which led to the aortic cannula of the experimental heart and a pressure-limiting side-arm which overflowed when 100 $\mathrm{mmHg}$ pressure was exceeded. The venous cannula of the second dog was connected to the right-heart cannula of the experimental heart, and to a funnel in which the heart was to lie and into which the arterial overflow also fed. The circuit was primed with Hartmann's solution, which was exchanged with blood from the support dog. The cavae of the experimental heart were tied and, while the heart emptied itself, the aorta below the subclavian, the brachiocephalic artery, and the pulmonary artery were then tied in that order, the 'support' circulation was begun, and the right heart cannula was unclamped. There was thus minimal mixing of blood from the two dogs, yet the experimental heart was perfused without interruption. The aorta, the subclavian, brachiocephalic, and pulmonary arteries and the cavae were then divided below the ligatures. The heart was fibrillated electrically before the left atrium was opened, the pulmonary veins divided, and the now free heart placed in the supporting funnel. A fine Latex balloon of over $50 \mathrm{ml}$ capacity was held in the left ventricle with a stitch round the free edge of the mitral valve tightened round a flange connecting the balloon to a pressure transducer and a graduated syringe. Measured fluid was added to the balloon to raise the pressure above $5 \mathrm{mmHg}$, when electrical defibrillation was performed. The heart was paced at a rate of 120 beats/min via the atria. Surface electrocardiographic leads and an intramural temperature probe were affixed. A small perforated tube was put into the left ventricle to let out any blood accumulating alongside the balloon (Fig. 1). Fluid was added in $2 \mathrm{ml}$ increments to raise

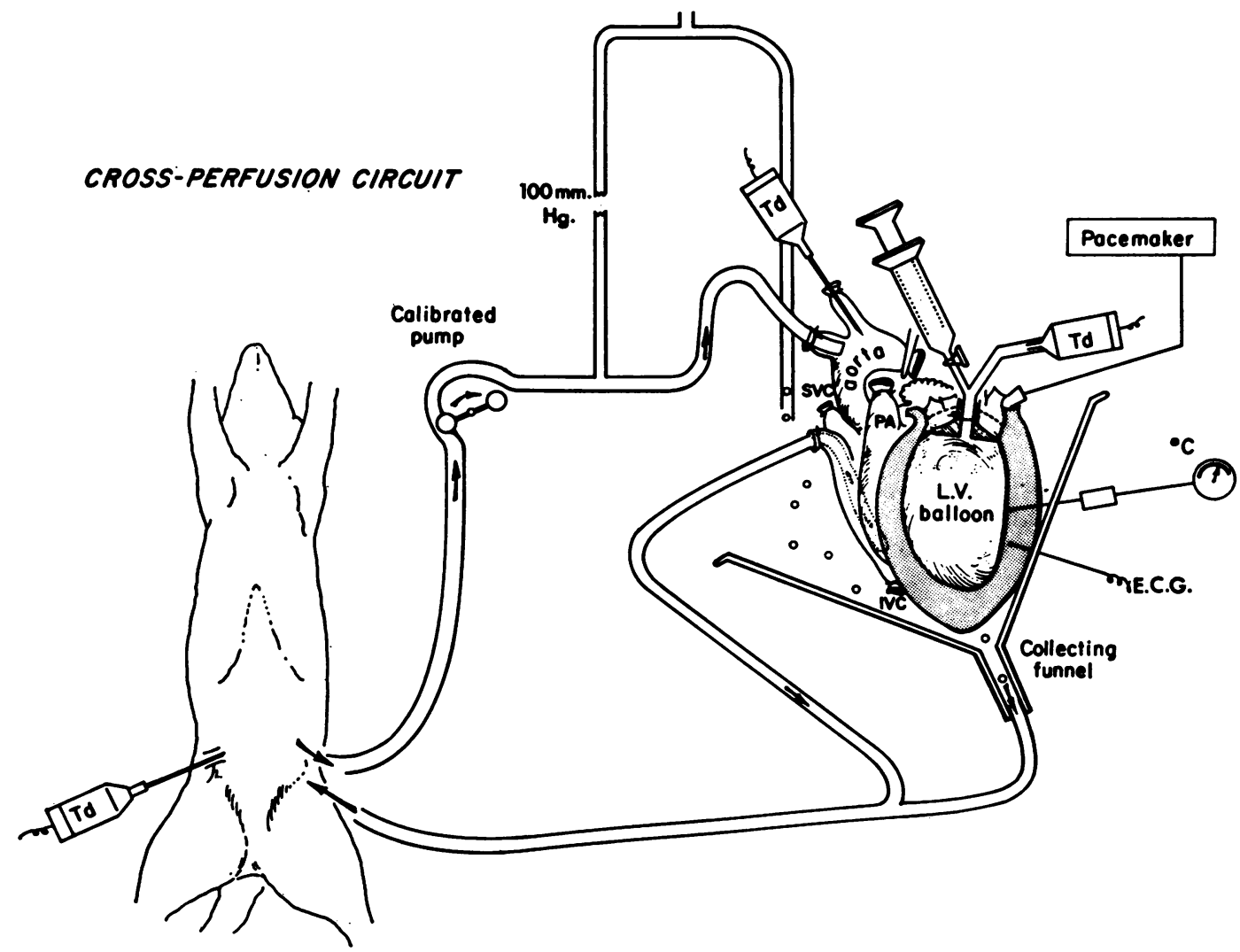

FIG. 1. The layout of the experimental preparation: Td=pressure transducer; E.C.G.=electrocardiograph lead; $S V C=$ superior vena cava; $I V C=$ inferior vena vava; $P A=$ pulmonary urtery. 
INITIAL

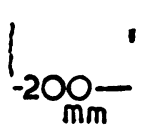

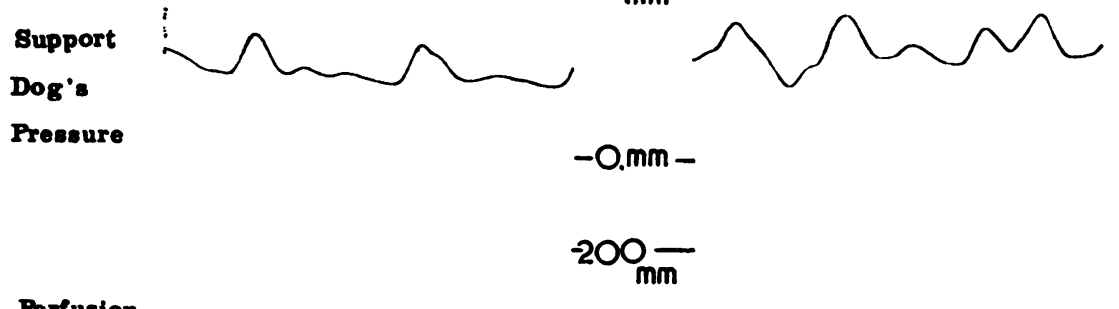

Perfusion

Pressure

$-0 . m m-$

E.C.G.

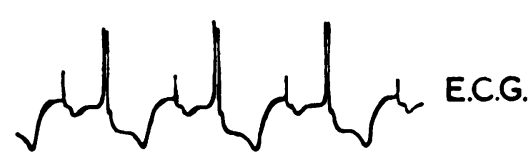

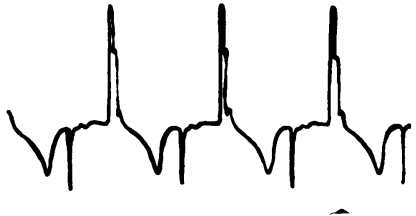

$\mathrm{Dp} / \mathrm{Dt}$

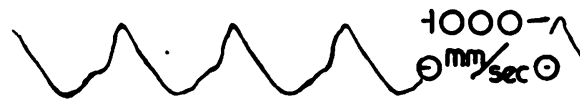<smiles>CCCCCCCCCCCC</smiles>

Diastolic

7

$\sqrt{7}$

$\sqrt{\sqrt{20 m m-}}$

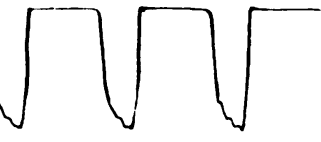

Pressure

$$
\text { 500c }
$$$$
-0 . m m-
$$

B2cc

$$
-200 \frac{\mathrm{mm}}{-}
$$

Systolic

Pressure

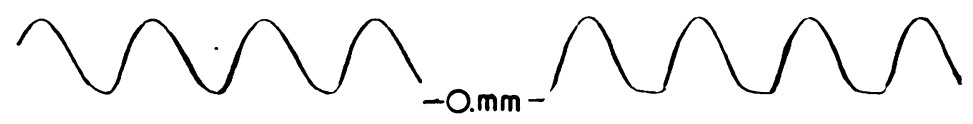

FIG. 2. Initial and final traces from a heart supported with continuous normothermic crossperfusion for two hours. E.C.G. =electrocardiogram; $D p / D t=$ rate of change of intraventricular pressure. 
INITIAL

FINAL
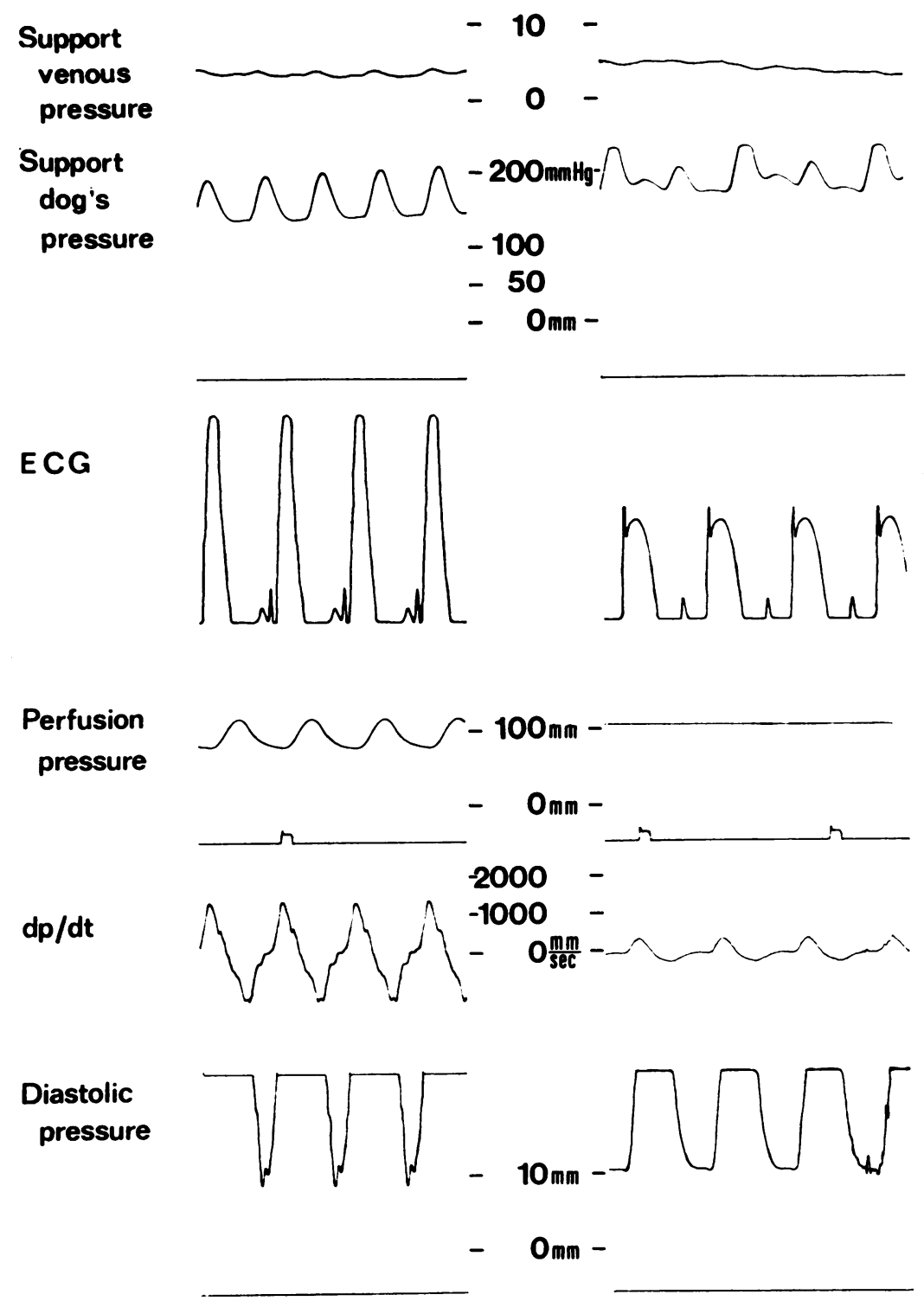

$$
-200 m m-
$$

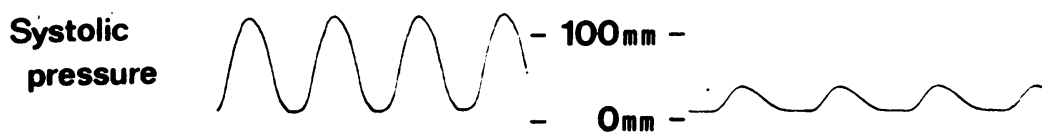

FIG. 3. Initial and final traces from a heart supported with intermittent normothermic crossperfusion for three minutes every 13 minutes during two hours. ECG=electrocardiogram; $d p / d t=$ rate of change of intraventricular pressure. 


\section{Support dog's pressure}

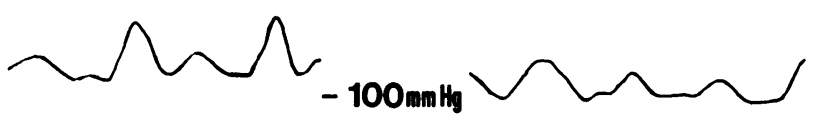

- 0 mm -

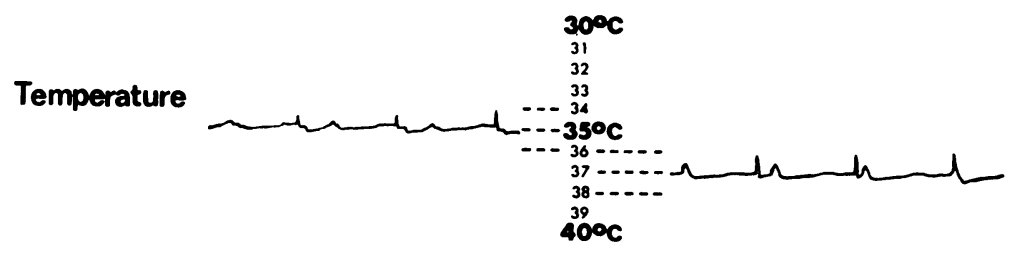

ECG
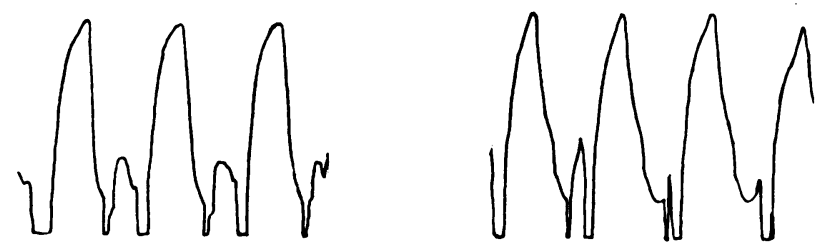

\section{Perfusion pressure}

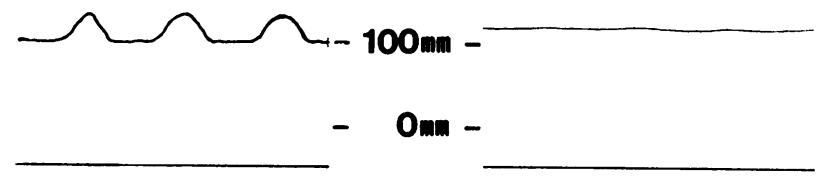

$\mathrm{dp} / \mathrm{dt}$

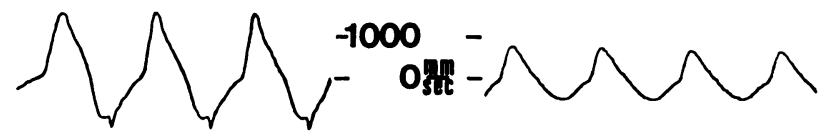

Diastolic pressure<smiles>CCCC</smiles><smiles>CCCCCCC</smiles><smiles>CC=CCCC=CCC=CO[O-]</smiles>

Systolic $-200 \mathrm{~mm}$ pressure

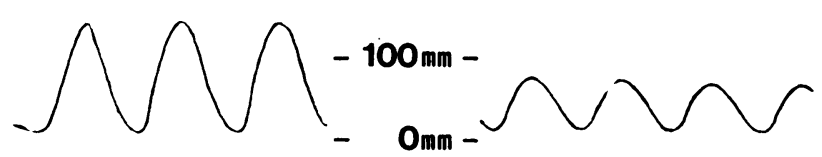

FIG. 4. Initial and final traces from a heart supported with intermittent cool cross-perfusion for three minutes every 13 minutes throughout two hours. ECG=electrocardiogram; dp/dt = rate of change of intraventricular pressure. 
the end-diastolic pressure in the ventricle from 0 to $10 \mathrm{mmHg}$, recording a few beats at each volume. At the end of this initial ventricular function test a biopsy was taken from the apex of the ventricle with a highspeed air drill and immediately chilled for cryosectioning. The perfusion technique to be applied to the heart was then started: perfusion with blood at body temperature from the support dog was continued in seven hearts (Fig. 2); ischaemia for periods of 10 minutes with normothermic perfusion for three minutes each time was applied to 10 hearts (Fig. 3); and the same intermittent perfusion regime was applied at a temperature of $30^{\circ} \mathrm{C}$ to 10 hearts (Fig. 4). Two hours of this treatment, with enough fluid in the balloon to keep the end-diastolic pressure in the ventricle above $0 \mathrm{mmHg}$ and the hearts beating but not paced, then ensued. Continuous normothermic perfusion then continued, allowing the heart to recover, if necessary, for a period of up to one hour before the final ventricular function test and biopsy. Perfusion was then stopped, and the left ventricle was dissected from the rest of the heart; its natural capacity, weight, and volume by displacement were then measured as well as the weight of the whole heart.

\section{RESULTS}

PEAK SYSTOLIC PRESSURE The hearts maintained with constant normothermic perfusion developed a higher peak systolic pressure relative to the initial level than those maintained with intermittent cool perfusion, which in turn produced higher pressures relative to the initial level than those which had intermittent normothermic perfusion. The difference between the intermittently normothermic perfused hearts and both other groups was statistically significant (Table I). The difference between the normothermic constantly perfused hearts and the cooled intermittently perfused ones was not significant.

T A B L E I

PEAK SYSTOLIC PRESSURE AT END-DIASTOLIC PRESSURE OF $10 \mathrm{mmHg}$ AFTER TWO HOURS OF PRESERVATION, EXPRESSED AS PERCENTAGES OF INITIAL VALUES

\begin{tabular}{|c|c|c|c|c|c|c|c|}
\hline \multirow[t]{2}{*}{ Group } & \multirow[t]{2}{*}{$\begin{array}{c}\text { No. } \\
\text { of } \\
\text { Group }\end{array}$} & \multirow[t]{2}{*}{ No. } & \multirow[t]{2}{*}{ Mean } & \multirow{2}{*}{$\begin{array}{l}95 \% \\
\text { Conf- } \\
\text { dence } \\
\text { Range }\end{array}$} & \multicolumn{3}{|c|}{ T Values-Groups } \\
\hline & & & & & 1 & 2 & 3 \\
\hline \multirow{4}{*}{$\begin{array}{l}\text { Control } \\
30^{\circ} \\
\text { intermittent } \\
\text { perfusion } \\
37^{\circ} \\
\text { intermittent } \\
\text { perfusion }\end{array}$} & \multirow[t]{2}{*}{1} & \multirow[b]{2}{*}{10} & \multirow{2}{*}{$\begin{array}{r}114 \cdot 0 \\
89 \cdot 3\end{array}$} & \multirow{2}{*}{$\begin{array}{c}82.6 \\
157.0 \\
67.6- \\
117.8\end{array}$} & \multirow[b]{2}{*}{$>0.1$} & \multirow[t]{2}{*}{$1 \cdot 1$} & \multirow{3}{*}{$\begin{array}{l}4 \cdot 2 \\
3 \cdot 2\end{array}$} \\
\hline & & & & & & & \\
\hline & \multirow[t]{2}{*}{3} & \multirow[t]{2}{*}{9} & \multirow[t]{2}{*}{$45 \cdot 0$} & \multirow{2}{*}{$\begin{array}{l}33 \cdot 6- \\
60 \cdot 3\end{array}$} & $<0.0005$ & $<0.005$ & \\
\hline & & & & & \multicolumn{3}{|c|}{ P Values } \\
\hline
\end{tabular}

PEAK RATE OF RISE OF PRESSURE (Table II) The rate of rise of pressure at an end-diastolic pressure of $10 \mathrm{mmHg}$ at the end of the preservation period
T A B LE II

RATE OF RISE OF PRESSURE AT END-DIASTOLIC PRES. SURE OF $10 \mathrm{mmHg}$ AFTER TWO HOURS OF PRESERVATION, EXPRESSED AS PERCENTAGES OF INITIAL VALUES

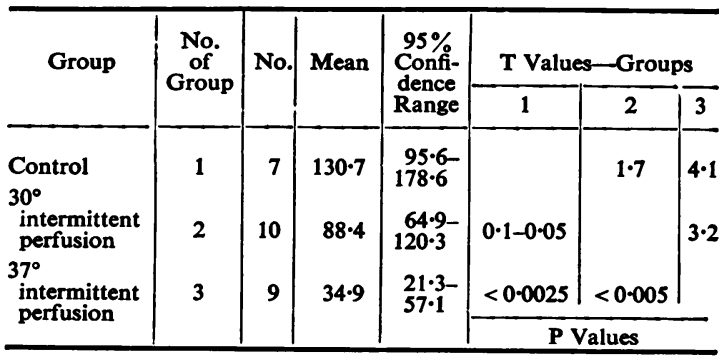

relative to that at the beginning was highest in the groups of hearts maintained with normothermic constant perfusion, intermediate in the hearts perfused intermittently at $30^{\circ} \mathrm{C}$, and lowest in those intermittently perfused at $37^{\circ} \mathrm{C}$. The levels of statistical significance are shown in the table, and are highest for the difference between the normothermic intermittently perfused hearts and the other two groups.

COMPLIANCE OF THE VENTRICLES (Table III) The difference in volume in the ventricle between the end-diastolic pressures of 0 and $10 \mathrm{mmHg}$ at the end of the maintenance period relative to that initially was also highest in the hearts perfused continuously, next highest in those cooled to $30^{\circ} \mathrm{C}$ and intermittently perfused, and lowest in those intermittently perfused at $37^{\circ} \mathrm{C}$. The difference between the first and last groups just fails to reach statistical significance.

\section{T A B L E I I I}

COMPLIANCE OF THE VENTRICLES-THE CHANGE IN VOLUME PRODUCING AN END-DIASTOLIC PRESSURE OF $10 \mathrm{mmHg}$ AT END OF PROCEDURE, EXPRESSED AS PERCENTAGES OF INITIAL VALUES

\begin{tabular}{l|c|c|c|c|c|c|c}
\hline \multicolumn{1}{|c|}{ Group } & $\begin{array}{c}\text { No. } \\
\text { of } \\
\text { Group }\end{array}$ & No. & Mean & $\begin{array}{c}95 \% \\
\text { Confi- } \\
\text { dence } \\
\text { Range }\end{array}$ & T Values-Groups \\
\hline $\begin{array}{l}\text { Control } \\
\begin{array}{l}30^{\circ} \\
\text { intermittent } \\
\text { perfusion }\end{array}\end{array}$ & 2 & 10 & 59.6 & $\begin{array}{c}39 \cdot 2- \\
90.5\end{array}$ & $>0.1$ & 2 & 3 \\
$\begin{array}{l}37^{\circ} \\
\text { intermittent } \\
\text { perfusion }\end{array}$ & 3 & 9 & 48.8 & $\begin{array}{c}28.1- \\
84.7\end{array}$ & $0.1-0.05$ & $>0.1$ & 1.6 \\
\hline
\end{tabular}

HISTOCHEMISTRY AND BIREFRINGENCE (Tables IVVI) The signs of damage seen by changes of staining with acid-haematein and succinic dehydrogenase stains were graded from 0 to 4 by an observer unaware of the source of the samples 
T A B L E I V

SUCCINIC DEHYDROGENASE DISTRIBUTION IN MYOCARDIUM; DEGREES OF DAMAGE FROM 0 (NORMAL) TO 4 (GROSS) AT END OF PERFUSION PERIOD, EXPRESSED AS PERCENTAGES OF INITIAL VALUES

\begin{tabular}{|c|c|c|c|c|c|c|c|}
\hline \multirow[t]{2}{*}{$\begin{array}{l}\text { Group } \\
\text { L No. }\end{array}$} & \multirow[t]{2}{*}{$\begin{array}{l}\text { Perfusion } \\
\text { Technique }\end{array}$} & \multirow[t]{2}{*}{ No. } & \multirow[t]{2}{*}{ Mean } & \multirow{2}{*}{$\begin{array}{l}95 \% \\
\text { Conf- } \\
\text { dence } \\
\text { Range }\end{array}$} & \multicolumn{3}{|c|}{ T Values-Groups } \\
\hline & & & & & 1 & 2 & 3 \\
\hline 1 & Control & 7 & $125 \cdot 8$ & $\begin{array}{c}94 \cdot 1- \\
168 \cdot 3\end{array}$ & & 1.0 & 0.7 \\
\hline 2 & $\begin{array}{l}30^{\circ} \text { inter- } \\
\text { mittent }\end{array}$ & 10 & $108 \cdot 4$ & $\begin{array}{r}92 \cdot 6- \\
126 \cdot 9\end{array}$ & $>0.1$ & & $1 \cdot 8$ \\
\hline \multirow[t]{2}{*}{3} & $\begin{array}{l}\text { perfusion } \\
\text { Normother- }\end{array}$ & 9 & $144 \cdot 9$ & $\begin{array}{l}110 \cdot 2- \\
190 \cdot 6\end{array}$ & $>0.1$ & $<0.05$ & \\
\hline & $\begin{array}{l}\text { mittent } \\
\text { perfusion }\end{array}$ & & & & \multicolumn{3}{|c|}{ P Values } \\
\hline
\end{tabular}

T A B LE V

FREE PHOSPHOLIPIDS (BY ACID HAEMATENN STAIN); DEGREE OF CHANGE FROM O (NORMAL) TO 4 (GROSS) AT END OF PERFUSION PERIOD, AS PERCENTAGES OF INITIAL

\begin{tabular}{|c|c|c|c|c|c|c|c|}
\hline \multirow[t]{2}{*}{$\begin{array}{c}\text { Group } \\
\text { No. }\end{array}$} & \multirow[t]{2}{*}{$\begin{array}{l}\text { Perfusion } \\
\text { Technique }\end{array}$} & \multirow[t]{2}{*}{ No. } & \multirow[t]{2}{*}{ Mean } & \multirow{2}{*}{$\begin{array}{l}95 \% \\
\text { Confi- } \\
\text { dence } \\
\text { Range }\end{array}$} & \multicolumn{3}{|c|}{ T Values-Groups } \\
\hline & & & & & 1 & 2 & 3 \\
\hline 1 & Control & 7 & $114 \cdot 9$ & $\begin{array}{c}87 \cdot 5- \\
150 \cdot 9\end{array}$ & & $1 \cdot 2$ & $0 \cdot 7$ \\
\hline 2 & \multirow{3}{*}{$\begin{array}{l}30^{\circ} \\
\text { inter- } \\
\text { mittent } \\
\text { perfusion } \\
\text { Normother- } \\
\text { mic inter- } \\
\text { mittent } \\
\text { perfusion }\end{array}$} & 10 & $100 \cdot 0$ & $100 \cdot 0$ & $>0 \cdot 1$ & & $2 \cdot 1$ \\
\hline 3 & & \multirow[t]{2}{*}{9} & \multirow[t]{2}{*}{$130 \cdot 8$} & \multirow{2}{*}{$\begin{array}{l}100 \cdot 5- \\
170 \cdot 1\end{array}$} & $>0 \cdot 1$ & $<0.05$ & \\
\hline & & & & & \multicolumn{3}{|c|}{ P Values } \\
\hline
\end{tabular}

T A B LE V I

INDEX OF BIREFRINGENCE-RATIO OF BIREFRINGENCE AFTER ATP AND CALCIUM TO THAT BEFORE IT; VALUES AT END OF PERFUSION. AS PERCENTAGES OF INITIAL

\begin{tabular}{|c|c|c|c|c|c|c|c|}
\hline \multirow[t]{2}{*}{$\begin{array}{c}\text { Group } \\
\text { No. }\end{array}$} & \multirow[t]{2}{*}{$\begin{array}{c}\text { Perfusion } \\
\text { Technique }\end{array}$} & \multirow[t]{2}{*}{ No. } & \multirow[t]{2}{*}{ Mean } & \multirow{2}{*}{$\begin{array}{l}95 \% \\
\text { Confi- } \\
\text { dence } \\
\text { Range }\end{array}$} & \multicolumn{3}{|c|}{ T Values-Groups } \\
\hline & & & & & 1 & 2 & 3 \\
\hline 1 & Control & 7 & $24 \cdot 6$ & $\begin{array}{l}21 \cdot 6- \\
28 \cdot 0\end{array}$ & & $1 \cdot 2$ & 1.5 \\
\hline 2 & $\begin{array}{l}30^{\circ} \\
\text { inter- } \\
\text { mittent } \\
\text { perfusion } \\
\text { Normo- }\end{array}$ & 10 & $27 \cdot 9$ & $\begin{array}{l}23.9- \\
32 \cdot 5 \\
23 \cdot 0-\end{array}$ & $0.1-0.05$ & $>0.1$ & $1 \cdot 2$ \\
\hline 3 & $\begin{array}{l}\text { inter- } \\
\text { mittent } \\
\text { perfusion }\end{array}$ & & & & \multicolumn{3}{|c|}{ P Values } \\
\hline
\end{tabular}

and the ratio of the initial to the final figure found. Figures greater than $100 \%$ imply damage. The post-perfusion ratio of the birefringence of the muscle fibrils after/before the application of adenosine triphosphate and calcium relative to this ratio - 'the index of birefringence' at the beginning of the experiment-is also compared. Enzymes such as succinic dehydrogenase seem best preserved by cooling, next best by continuous perfusion, and least by intermittent warm perfusion. The normal phospholipid pattern was also preserved in this order of excellence. Both stains show statistically significant benefit from cooling in conjunction with intermittent perfusion. The index of birefringence was nearest to the initial levels in the intermittently perfused normothermic preparations, next in the cooled ones, and furthest from the original in the continuously perfused hearts. None of these differences was statistically significant.

HISTOLOGY (Table VII) Graded signs of damage, from 0 to 4 , were noted by an independent observer, and the ratio of these grades after preservation to the initial levels was found. All of the hearts had more such signs at the end of the experiment than at the beginning, mostly in the form of signs of oedema of the cells; the changes were greatest in the normothermically constantly perfused hearts, and least in those perfused intermittently at $37^{\circ} \mathrm{C}$. None of these differences was statistically significant.

\section{T A B LE VII}

HISTOLOGICAL SIGNS OF DAMAGE IN MYOCARDIUM GRADE OF DAMAGE FROM 0 (NORMAL) TO 4 (GROSS) AT END OF PERFUSION. AS PERCENTAGES OF INITIAL VALUES

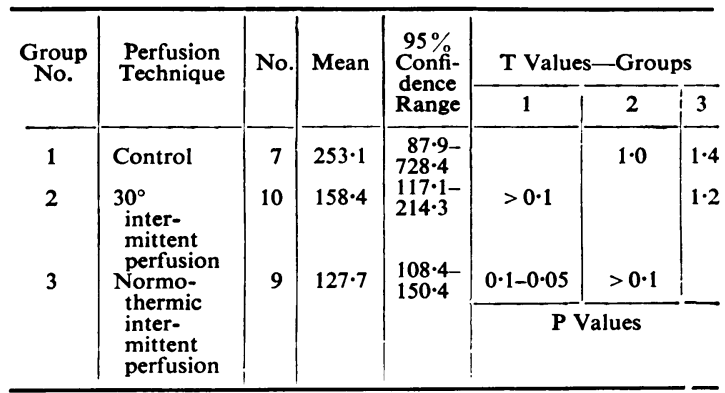

OEDEMA OF THE VENTRICLE (Table VIII) Since no preoperative weight of the isolated ventricle could be obtained, the weight of the ventricle, dissected free from all the other heart chambers, is expressed as a ratio of the weight of the animal from which it came. As the animals were all pure-bred of the same breed these weights are comparable. The constantly perfused hearts accumulated the least weight, and those which were cooled accumulated the most. No difference reached statistically significant levels. 
T A B L E VIII

OEDEMA OF MYOCARDIUM-WEIGHT OF VENTRICLES AT END OF PERFUSION PERIOD RELATIVE TO TOTAL WEIGHT OF ANIMAL, EXPRESSED AS GRAMMES OF HEART PER KILOGRAMME OF LIVE ANIMAL

\begin{tabular}{c|c|c|c|c|c|c|c}
\hline $\begin{array}{c}\text { Group } \\
\text { No. }\end{array}$ & $\begin{array}{l}\text { Perfusion } \\
\text { Technique }\end{array}$ & No. & Mean & $\begin{array}{c}95 \% \\
\text { Confi- } \\
\text { dence } \\
\text { Range }\end{array}$ & T Values-Groups \\
\hline 1 & $\begin{array}{l}\text { Control } \\
2\end{array}$ & 7 & 7.8571 & $\begin{array}{c}6.446 \\
9.268\end{array}$ & & 2 & 3 \\
\hline 3 & $\begin{array}{l}30^{\circ} \\
\text { inter- } \\
\text { mittent } \\
\text { perfusion } \\
\text { Normo- } \\
\text { thermic } \\
\text { inter- } \\
\text { mittent } \\
\text { perfusion }\end{array}$ & 9 & 8.3356 & 9.0392 & $\begin{array}{c}7.950-3 \\
10.128\end{array}$ & $>0.1$ & 0.6 \\
\hline
\end{tabular}

DISCUSSION

The results of these experiments showed that the myocardium was best maintained by continuous normothermic perfusion, next best by intermittent cool perfusion, and least well by intermittent normothermic perfusion, in the preparation used and by the methods of assessment employed. Any clinical applications of these findings presuppose the validity of the isolated cross-perfused canine heart preparation and of the techniques of evaluation of ventricular function and histochemical response. This validity and the findings of others on the results of exposing the heart to cold or anoxia merit discussion.

EXPERIMENTAL PREPARATION The isolated heart is a sensitive preparation, especially to anoxia (Blackstone et al., 1968), and deteriorates spontaneously with artificial perfusion and oxygenation. The cross-perfused isolated heart is very stable, however (Webb, 1969), and is a good model for assessment of preservation (Holdefer and Edwards, 1968). The hypertrophy that so frequently accompanies clinical situations demanding open-heart surgery makes the heart more vulnerable to anoxia because of a reduced ratio of mitochondria to myocardium (Lundesgaard-Hansen, 1966), and more difficult to cool evenly (Vasko, 1967), so any experimental results showing the inferiority of cooling or anoxia to normothermic continuous perfusion apply even more strongly to the clinical situation.

METHODS OF ASSESSMENT The isovolumic technique used permitted estimation of the compliance of the ventricles without difficulty, an important advantage since changes in compliance may mimic failure changes in the end-diastolic pressure (Diamond and Forrester, 1972). The estimate of the changes in volume over the 0 to $10 \mathrm{mmHg}$ end-diastolic pressure range rather than the total ventricular volume at $10 \mathrm{mmHg}$ end-diastolic pressure seems to be a more useful index of compliance (Brown, Braimbridge, Niles and Austen, 1973a). The simple measurements of peak systolic pressure and peak rate of rise of pressure at the end-diastolic pressure of $10 \mathrm{mmHg}$ are as useful as means of demonstrating adverse changes in preserved hearts as are changes in tension, developed tension or velocity of contractile elements, which are much more difficult to calculate (Brown et al., 1973a).

Recent developments in direct examination of the myocardium promise great clinical usefulness. Intramyocardial gas tension evaluation may predict which anoxic myocardium will survive (Brantigan, Perna, and Gott, 1970). Full-thickness drill biopsy of the septum by means of cardiac catheter techniques offers the advantages of a nonsurgical investigation without the disadvantages of inadequate endocardial pinch-biopsy sampling (Bulloch et al., 1972). Examination of the biopsy by adenosine triphosphatase (Swynghedauw et al., 1971), tetrazolium test (Abbott, 1969), and haematoxylin basic fuchsin picric acid (Lie et al., 1971) are all claimed to have predictive value for myocardial survival. Myocardial contraction depends on the integrity of the cell membrane, transport of hydrogen, and the conversion of highenergy phosphates into mechanical work, therefore the acid-haematein test for free phospholipids, the examination of succinic dehydrogenase distribution, and the myosin adenosinetriphosphatase as reflected in myofibrillar birefringence were chosen as the most relevant tests. Free phospholipids, raised in cardiac overstimulation (Ferrans et al., 1969), are probably an index of initial myocardial state, not changing in short experiments, whereas the succinic dehydrogenase distribution parallels short-term changes in function (Brown et al., 1973a) except where cold preservation has preserved the enzyme pattern but not the function.

MYOCARDIAL COOLING For many surgeons, myocardial cooling is a complete substitute for perfusion; the duration of its protection depends on its degree (Angell et al., 1969). It has been used with success for seven hours (Lower et al., 1962) and, by some, is preferred to perfusion (Robicsek et al., 1970). Used with ether anaesthesia (Barnes, Mohri, and Merendino, 1968) or slow pacing (Mohri, 1965), fibrillation may be avoided, though this is not damaging over short periods (Martino et al., 1969). Cold is certainly preferable to chemi- 
cal arrest (Greenberg, Edmunds, and Brown, 1960) but even after 15 minutes at $16^{\circ} \mathrm{C}$ the coronary sinus potassium and calcium levels were lower and the magnesium level was higher (Urschel and Greenberg, 1960). Cooling patients produces abnormalities in levels of insulin, growth hormone, and catecholamine and of fatty acid uptake (Moffitt et al., 1971), and though it preserves the histochemical pattern of the myocardium it reduces mechanical performance and produces oedema (Brown, Niles, Braimbridge, and Austen, 1973b) with associated osmotically-produced ultrastructural changes (Ferrans et al., 1970).

MYOCARDIAL ANOXIA The duration of anoxia seemed directly related to the resultant myocardial depression in a trial conducted with a performancereducing oxygenator (Sarin, Hall, and Ross, 1968). This expected conclusion confirmed the impressions of earlier workers (Ebert et al., 1962) who found that protection from anoxia resulted from cooling or intermittent cool perfusion. Examination of the lymph flowing from the heart (Ullal, 1972) suggests that the worst damage to the heart comes from normothermic anoxia, less from cooling, and least from continuous normothermic perfusion. The results of the present experiments confirm this, with quantitative estimates of structure and function and statistically significant differences.

Though the practical attractions of ischaemic cardiac arrest for open-heart surgery may be accompanied by improved operative precision and survival in operations lasting around one hour, our work and that of others suggest that when the operating time is to be in the two-hour range, continuous normothermic perfusion should preserve the myocardium best, followed by intermittent hypothermic perfusion, with intermittent normothermic perfusion the least desirable.

\section{REFERENCES}

Abbott, W. M. (1969). Viability assays as applied to the cryopreservation of hearts and kidneys. Cryobiology, $5,454$.

Angell, W. W., Rikkers, L., Dong, E., and Shumway, N. E. (1969). Organ viability with hypothermia. Journal of Thoracic and Cardiovascular Surgery, 58, 619.

Barnes, R. W., Mohri, H., and Merendino, K. A. (1968). Experimental aortic valve homotransplantation without cardiopulmonary bypass. Surgery, 64, 647.

Bayley, R. H. (1942). An interpretation of the injury and the ischemic effects of myocardial infarction in accordance with the laws which determine the flow of electric currents in homogeneous volume conductors, and in accordance with relevant pathologic changes. American Heart Journal, 24, 514.
Benzing, G., III, Helmsworth, J., Stockert, J., and Kaplan S. (1970). Human myocardial performance during surgical treatment of cardiac defects. Journal of Thoracic and Cardiovascular Surgery, 59, 800.

Björk, V. O. (1967). Safety factors in open-heart surgery. Journal of Thoracic and Cardiovascular Surgery, 54, 161.

Blackstone, E. H., Evans, R. H., Eckner, F. A. O., Drake, A., and Moulder, P. V. (1968). Perfusion-induced myocardial injury. Journal of Thoracic and Cardiovascular Surgery, $56,689$.

Bloodwell, R. D., Gill, S. S., Pereyo, J. A., Hallman, G. L., deBakey, M. E., and Cooley, D. A. (1966). Cardiac valve replacement without coronary perfusion. Circulation, 33, Suppl. III, 58.

Bolooki, H., Rooks, J. J., Viera, C. E., Smith, B., MobinUddin, K., Lombardo, C. R., and Jude, J. R. (1968). Comparison of the effect of temporary or permanent myocardial ischemia on cardiac function and pathology. Journal of Thoracic and Cardiovascular Surgery, 56, 590.

Braimbridge, M. V. and Niles, N. R. (1964). Left ventricular drill biopsy. Journal of Thoracic and Cardiovascular Surgery, 47, 685.

Brantigan, J. W., Perna, A. M., and Gott, V. L. (1970). Intramyocardial gas tensions during anoxic cardiac arrest. Surgical Forum, 21, 152.

Brown, A. H., Braimbridge, M. V., Niles, N. R., and Austen, W. G. (1973a). Assessment of the heart by histochemistry and birefringence compared with ventricular function tests. Journal of Surgical Research (in press).

_- - — - Gerbode, F., and Aguilar, M. J. (1969). The effect of excessively high perfusion pressures on the histology, histochemistry, birefringence and function of the myocardium. Journal of Thoracic and Cardiovascular Surgery, 58, 655.

, Niles, N. R., Braimbridge, M. V., and Austen, W. G. (1973b). Preservation of the myocardium by means of cold physiological solutions, as assessed by ventricular function, histochemistry and birefringence. Journal of Surgical Research, 14, 46.

Buja, L. M., Levitsky, S., Ferrans, V. J., Souther, S. G., Roberts, W. C., and Morrow, A. G. (1971). Acute and chronic effects of normothermic anoxia on canine hearts. Circulation, 43, Suppl. 1, 44.

Bulloch, R. T., Pearce, M. B., Murphy, M. L., Jenkins, B. J., and Davis, J. L. (1972). Myocardial lesions in idiopathic and alcoholic cardiomyopathy. Study by ventricular septal biopsy. American Journal of Cardiology, 29, 15.

Calman, K. C., Quin, R. O., Macpherson, S. G., and Bell, P. R. F. (1971). The effect of $\mathrm{pH}$ and infusion volume on organ preservation (abstract). British Journal of Surgery, 58, 865.

Caulfield, J., and Klionsky, B. (1959). Myocardial ischemia and early infarction. An electron microscopic study. American Journal of Pathology, 35, 489.

Chayen, J., Altmann, F. P., Bitensky, L., Braimbridge, M. V., Kadas, T., and Wells, P. J. (1966). A study of the changes in hydrogen transport in an isolated rat heart preparation. Journal of the Royal Microscopical Society, 86, 151.

Childs, J. W. and Lower, R. R. (1969). Preservation of the heart. Progress in Cardiovascular Disease, 12, 149.

Colapinto, N. D. and Silver, M. D. (1971). Prosthetic heart-valve replacement. Causes of early post-operative death. Journal of Thoracic and Cardiovascular Surgery, 61, 938. 
Cross, C. E., Reiben, P. A., and Salisbury, P. F. (1961). Influence of coronary perfusion and myocardial edema on pressure-volume diagram of left ventricle. American Journal of Physiology, 201, 102.

Diamond, G. and Forrester, J. S. (1972). The effect of coronary artery disease and acute myocardial infarction on left ventricular compliance in man. Circulation, $\mathbf{4 5}$, 11.

Ebert, P. A., Greenfield, L. J., Austen, W. G., and Morrow, A. G. (1962). Experimental comparison of methods for protecting the heart during aortic occlusion. Annals of Surgery, 155, 25.

Ecker, R. R., Najem, A. Z., Cyrus, R. J., Webb, W. R., and Sugg, W. L. (1969). The late effects of anoxic arrest on cardiac contractility. Surgical Forum, 20, 58.

Enright, L. P., Staroscik, R. N., and Reis, R. L. (1970). Left ventricular function after occlusion of the ascending aorta; assessments of various methods for myocardial protection. Journal of Thoracic and Cardiovascular Surgery, 60, 737.

Ferrans, V. J., Hibbs, R. G., Walsh, J. J., and Burch, G. E. (1969). Histochemical and electron microscopical studies on the cardiac necroses produced by sympathomimetic agents. Annals of the New York Academy of Sciences, 156, 309.

—, Levitsky, S., Buja, L. M., Williams, W. H., McIntosh, C. L., and Roberts, W. C. (1970). Histological and ultrastructural studies on preserved hearts. Circulation, 41, 42, Suppl. II, 104.

Gardner, T. J., Brantigan, J. W., Perna, A. M., Bender, H. W., Brawley, R. K., and Gott, V. L. (1971). Intramyocardial gas tensions in the human heart during coronary artery-saphenous vein bypass. Journal of Thoracic and Cardiovascular Surgery, 62, 844.

Goldman, B. S., Trimble, A. S., Sheverini, M. A., Teasdale, S. J., Silver, M. D., and Elliott, G. E. (1971). Functional and metabolic effects of anoxic cardiac arrest. Annals of Thoracic Surgery, 11, 122.

Greenberg, J. J., Edmunds, L. H., and Brown, R. B. (1960). Myocardial metabolism and post-arrest function in the cold and chemically arrested heart. Surgery, 48, 31.

Hall, D. P., Singal, S. A., Moretz, W. H., Brackney, E. L., Butler, W. F., Maloy, W. C., Bernstein, V., and Ellison, R. G. (1960). Myocardial metabolism during elective cardiac arrest determined by biochemical analysis of multiple cardiac biopsies. Surgical Forum, 10, 540.

Holdefer, W. F. and Edwards, W. S. (1968). Ventricular performance characteristics in a metabolically supported isolated heart preparation: a model for evaluating cardiac storage methods. Surgical Forum, 19, 225.

Katz, A. M. (1968). Effects of interrupted coronary flow upon myocardial metabolism and contractility. Progress in Cardiovascular Diseases, 10, 450.

Kay, E. B., Noguira, C., Suzuki, A., Postigo, J., and Mendelsohn, D. (1961). Myocardial protection during aortic valvular surgery. Annals of Surgery, 154, suppl. 159.

Kent, S. P. (1966). Intracellular plasma protein: a manifestation of cell injury in myocardial ischaemia. Nature, 210, 1279.

Kobernick, S. D., Mandell, G. H., Zirkin, R. M., and Hashimoto, Y. (1963). Succinic dehydrogenase deficiency in idiopathic cardiomegaly. American Journal of Pathology, 43, 661.
Levitsky, S., Sloane, R. E., Mullin, E. M., McIntosh, C. L., and Morrow, A. G. (1971). Normothermic myocardial anoxia. Effects on the canine heart with left ventricular outflow obstruction. Annals of Thoracic Surgery, 11, 229.

- Williams, W. H., Detmer, D. E., McIntosh, C. L., and Morrow, A. G. (1970). A functional evaluation of the preserved heart. Journal of Thoracic and Cardiovascular Surgery, 60, 625.

Lie, J. T., Holley, K. E., Kampa, W. R., and Titus, J. L. (1971). New histochemical method for morphological diagnosis of early stages of myocardial ischemia. Mayo Clinic Proceedings, 46, 319.

Littler, W. A., Meade, J. B., Evans, C. C., and Davies, G. (1972). Serum aspartate transaminase changes following open-heart surgery with ischaemic arrest (with and without coronary artery perfusion). Thorax, 27, 102.

Londe, S. P. (1969). The isolated perfused heart : its physiology and metabolism. Surgical Forum, 20, 159.

Lower, R. R., Stofer, R. C., Hurley, E. J., Dong, E. Jr., Cohn, R. B., and Shumway, N. E. (1962). Successful homotransplantation of the canine heart after anoxic preservation for seven hours. American Journal of Surgery, 104, 302.

Lundesgaard-Hansen, P. (1966). Surgical aspects of cardiac metabolism. Surgery, Gynecology and Obstetrics, 122, 1095.

Martino, R. A., Kissack, A. S., Stuckey, J. H., Kavaler, F., and Fisher, V. J. (1969). Myocardial function after electrically-induced ventricular fibrillation. American Journal of Cardiology, 24, 537.

Moffitt, E. A., Rosevear, J. W., and McGoon, D. C. (1966). Myocardial metabolism during hypothermic coronary perfusion in man. Acta Anaesthesiologica Scandinavica, Suppl. 23, 696.

(1970). Myocardial metabolism in children having open-heart surgery. Journal of the American Medical Association, 211, 1518.

- Sessler, A. D., Molnar, G. D., and McGoon, D. C. (1971). Normothermia versus hypothermia for wholebody perfusion. Effects on myocardial and body metabolism. Anesthesia and Analgesia, 50, 505.

Mohri, H. (1965). Application of the electric pace maker of the heart under hypothermia. Experimental study on the maintenance of the cardiac action under deep hypothermia (16 degrees below). Journal of Cardiovascular Surgery, 6, 379.

Morales, A. R., Fine, G., and Taber, R. E. (1967). Cardiac surgery and myocardial necrosis. Archives of Pathology, 83, 71 .

Mundth, E. D., Sokol, D. M., Levine, F. H., and Austen, W. G. (1969). Preservation of myocardial function during extended periods of coronary ischemia. Surgical Forum, 20, 176.

Niles, N. R. and Barnhouse, D. L. (1967). The acid hematein stain and myocardial damage. Archives of Pathology, 83, 407.

Pitzele, S., Sze, S., and Dobell, A. R. C. (1971a). Hypothermic plasma perfusion of the isolated heart. Surgery, 70, 407.

,--1 (1971b). Functional evaluation of the heart after storage under hypothermic coronary perfusion. Surgery, 70, 569. 
Ramsey, H. W., de le Torre, A., Linhart, J. W., and Wheat, M. W. (1967). Complications of coronary artery perfusion. Journal of Thoracic and Cardiovascular Surgery, 54, 714.

Reichenbach, D. D. and Benditt, E. P. (1968). Myofibrillar degeneration. A response of the myocardial cell to injury. Archives of Pathology, 85, 189.

Reul, G. J., Morris, G. C., Howell, J. F., Crawford, E. S., Sandiford, F. M., and Wukasch, D. C. (1971). The safety of ischemic cardiac arrest in distal coronary artery bypass. Journal of Thoracic and Cardiovascular Surgery, 62, 511.

Robicsek, F., Tam, W., Daugherty, H. K., and Mullen, D. C. (1970). Myocardial protection during openheart surgery-coronary perfusion versus topical cardiac hypothermia. Annals of Thoracic Surgery, 10, 340.

Salisbury, P. F., Cross, C. E., Katsuhara, K., and Rieben, P. A. (1961). Factors which initiate or influence edema in the isolated dog's heart. Circulation Research, 9, 601.

Sanmarco, M. E., Marquez, L. A., Hall, C., Philips, C. M., Gash, A., and Davila, J. C. (1969). Myocardial contractility following cardiopulmonary bypass with and without myocardial ischemia. Annals of Thoracic Surgery, 8, 237.

Sarin, C. L., Hall, R. W., and Ross, D. N. (1968). The effects of extracorporeal circulation on left ventricular function with and without anoxic arrest. Journal of Thoracic and Cardiovascular Surgery, 56, 395.

Shaw, R. F., Mosher, P., Ross, J. Jr., Joseph, J. I., and Lee, A. S. J. (1962). Physiologic principles of coronary perfusion. Journal of Thoracic and Cardiovascular Surgery, 44, 608.

Silcox, A. A., Poulter, L. W., Bitensky, L., and Chayen, J. (1965). An examination of some factors affecting histological preservation in frozen sections of unfixed tissue. Journal of the Royal Microscopical Society, 84, 559.

Singh, H. M. and Horton, E. H. (1971). Myocardial damage and valve replacements. Thorax, 26, 89.

Swynghedauw, B., Bouveret, P., Durand, M., Hatt, P. Y., Lemaire, F., and Piguet, V. (1971). Myofibriller and actomyosin adenosine-tri-phosphatase in experimental aortic insufficiency. Cardiovascular Research, 5, 458.
Taber, R. E., Morales, A. R., and Fine, G. (1967). Myocardial necrosis and the post-operative low-cardiacoutput syndrome. Annals of Thoracic Surgery, 4, 12.

Taggart, P., Slater, J. D. H., Carruthers, M. E., and McMillan, I. K. (1971). Effects of transient occlusion of coronary circulation on catecholamine and electrolyte gradients in human atrium (abstract). British Heart Journal, 33, 609.

Terasaki, P. I., Martin, D. C., and Smith, R. B. (1967). A rapid metabolism test to screen cadaver kidneys for transplantation. Transplantation, 5, 76.

Trimble, A. S., Bigelow, W. G., Wigle, E. D., and Silver, M. D. (1969). Coronary ostial stenosis. A late complication of coronary perfusion in open-heart surgery. Journal of Thoracic and Cardiovascular Surgery, 57, 792.

Ullal, S. R. (1972). Cardiac lymph and lymphatics. Annals of the Royal College of Surgeons of England, 51, 282.

Urschel, H. C. and Greenberg, J. J. (1960). Differential hypothermic cardioplegia. Surgical Forum, 10, 506.

Vasko, J. S. (Editorial) (1967). Preservation of myocardial function during open-heart surgery. American Journal of Surgery, 113, 589.

Veress, B., Kerényi, T., Hüttner, I., and Jellinek, H. (1966). The phases of muscle necrosis. Journal of Pathology and Bacteriology, 92, 511.

Verma, K. and King, D. W. (1966). Succinic dehydrogenase and isocitric dehydrogenase activities in vitamin Esufficient and -deficient fetal rats. Experientia, 22, 164.

Vitali-Mazza, L., Anversa, P., Morgutti, L., and Toso, A. (1969). Changes of the myocardial ultra-structure during open-heart surgery with extracorporeal circulation. Journal of Cardiovascular Surgery, 10, 212.

Webb, W. R. (1969). Cardiac preservation; current methods. Cryobiology, 5, 423.

—, Sugg, W. L., and Ecker, R. R. (1968). Heart preservation and transplantation. American Journal of Cardiology, 22, 820.

Willman, V. L., and Barner, H. B. (1969). Anatomical and physiological considerations in cardiac preservation. Cryobiology, 5, 413.

Yang, W. C. (1963). Anaerobic functional activity of isolated rabbit atria. American Journal of Physiology, 205, 781. 